ESKINAZI, Mara O., ENGEL, Pedro. Towards an elementary architecture. Thésis, Rio de Janeiro, v. 2, n. 3, p. 54-76, jan./ oct. 2017

submission date: $15 / 10 / 2016$ acceptance date: $25 / 04 / 2017$

\title{
Towards an elementary architecture
} Mara O. Eskinazi, Pedro Engel

Mara O. Eskinazi é Mestre em Arquitetura, Doutora em Urbanismo e professora na FAU-UFRJ; maraeskinazi@gmail.com.

Pedro Engel é Mestre em Arquitetura, Doutor em Arquitetura e professor na FAU-UFRJ; pedroengel@fau.ufrj.br

\begin{abstract}
The design teaching in the first year of the architecture courses has a propaedeutic character. That is, it should allow students to develop basic skills and knowledge that will enable them to undertake more complex activities in subsequent stages. In the architecture course of FAU UFRJ, the propaedeutics for the architectural project has been gradually transformed in the last two decades: it moved away from practices historically linked to the Bauhaus tradition of the Study of Form - based on the creation of plastic compositions of abstract character and on the understanding of their effects on perception - and towards the project of architecture and urbanism. This article presents the description of an exercise conceived in the discipline Conception of Architectural Form II, of the second semester of the architecture course in FAU / UFRJ, with the purpose of making explicit the pedagogical agenda of the discipline, which has among its premises the valuation of a so called "elementary architecture", which is based on the synthetism and visual elementarity of the object. The exercise consists of conceiving a project without a defined program, in a narrow urban lot, by means of manipulating an independent structure formed by pillars and beams and based on a modular frame. The focus is on the relationships between form, structure and space. This agenda, besides being a suited tool for teaching and reflecting on the project practice, also aligns itself with more pressing architectural problems in the construction of Brazilian cities. This is because it opens space for reflection on project principles based on the use of basic forms combined in a formal system compatible with the available constructive means, allied to spatial concepts and urban guidelines capable of guiding the occupation of these territories.
\end{abstract}

Keywords: design of form, design education, modulation, elementary architecture.

\section{Resumo}

O ensino de projeto no primeiro ano do curso de arquitetura possui caráter propedêutico. Isto é, deve possibilitar aos estudantes desenvolver habilidades e conhecimentos básicos que Ihes permitirão realizar atividades mais complexas nas etapas subsequentes. No curso de arquitetura da FAU UFRJ, a propedêutica para o projeto se transformou progressivamente nas duas últimas décadas: afastou-se das práticas historicamente vinculadas à tradição bauhausiana do Estudo da Forma - baseada na criação de composições plásticas de caráter abstrato e na compreensão dos seus efeitos sobre a percepção $\neg-$ e aproximou-se do projeto de arquitetura e urbanismo. Este artigo apresenta a descrição de exercício concebido na disciplina Concepção da Forma Arquitetônica II, do segundo semestre da FAU/UFRJ, com o objetivo de tornar explícita a agenda pedagógica da disciplina, que tem entre suas premissas a valorização de uma chamada arquitetura "elementar", que se baseie no sintetismo e na elementaridade visual do objeto. O exercício consiste em projeto de edificação sem programa definido, em lote urbano estreito, a partir da manipulação de uma estrutura independente formada por pilares e vigas e baseada numa trama mo- 
dular. O foco está nas relações entre forma, estrutura e espaço. Esta agenda, além de mostrar-se como ajustada ferramenta para ensino e reflexão sobre a prática de projeto, também alinha-se com problemas arquitetônicos mais prementes na construção das cidades brasileiras. Isso porque abre espaço para a reflexão acerca de princípios de projeto baseados no emprego de formas básicas combinadas em um sistema formal compatível com os meios construtivos disponíveis, aliados a conceitos espaciais e diretrizes urbanas capazes de nortear a ocupação desses territórios.

Palavras-chave: concepção da forma, ensino de projeto, modulação, arquitetura elementar.

\begin{abstract}
Resumen
La enseñanza del proyecto en el primer año de arquitectura tiene carácter propedéutico. Es decir, debe permitir a los estudiantes a desarrollar habilidades y conocimientos básicos que les permitan realizar actividades más complejas en etapas posteriores. En el curso de la arquitectura FAU UFRJ, la enseñanza propedéutica para el proyecto ha sido transformada poco a poco en las últimas dos décadas: se apartó de las prácticas históricamente vinculados a la tradición de la Bauhaus y del estudio de la forma - basada en la creación de composiciones visuales abstractas y en la comprensión de sus efectos sobre la percepción - y se acercó al diseño arquitectónico y urbano. En este artículo se presenta la descripción de un l ejercicio concebido en el curso de Concepción de la Forma Arquitectónica II, parte del segundo semestre del curso de arquitectura de la FAU / UFRJ, con el fin de hacer explícita la agenda pedagógica de la disciplina, que tiene entre sus premisas la valoración de una arquitectura denominada "elemental" que se basa en el sintetismo y en la elementalidad visual del objeto. El ejercicio consiste en el diseño de un edificio sin programa definido, en un solar urbano estrecho, mediante la manipulación de una estructura independiente formada por pilares y vigas y con base en una trama modular. La atención se centra en la relación entre forma, estructura y espacio. Esta agenda se muestra como herramienta ajustada para la enseñanza y la reflexión sobre la práctica de diseño y también se alinea con los problemas arquitectónicos más acuciantes en la construcción de las ciudades Brasileñas. Esto se debe a el espacio abierto para la reflexión sobre los principios de diseño basados en el uso de formas básicas acordadas en un sistema formal compatible con medios constructivos disponibles, combinados con conceptos espaciales y directrices urbanas capaz de guiar a la ocupación de estos territorios.
\end{abstract}

Palabras-clave: diseño de la forma, enseñanza del proyecto, modulación, arquitectura elemental.

\title{
Introduction: an agenda for teaching architectural design in the first year
}

$\mathbf{T}$ he teaching of design in the first year of the architecture course has propaedeutic character. That is, it should enable students to develop basic skills and knowledge that will enable them to undertake more complex activities in subsequent stages. In the architecture course of FAU UFRJ, the propaedeutic for the project have been gradually transformed in the last two decades: it moved away from ${ }^{1}$ practices historically linked to the Bauhaus tradition of the 
1 The exercise was conceived in 2012 by the group of effective teachers of the discipline - Ana Amora, Flavia de Faria, Mara Eskinazi and Pedro Engel. The conception of the exercise was based in part on the experience of Mara Eskinazi in the discipline of Architectural Design I at the Faculty of Architecture of UFRGS, taught by Professor Edson Mahfuz, in which a variant of the problem of 9 squares was applied as an initial exercise to the students.

2 The agenda of the TEMPU group, coordinated by prof. Guilherme Lassance and which also includes professors Ana Slade, Mara Eskinazi and Pedro Engel, is linked, among others, to the research "Infrastructure and urbanization in the periphery of metropolises: comparative analysis of land occupation patterns". The research is developed at PROURB - FAU / UFRJ.
Study of Form - based on the creation of plastic compositions of an abstract character and on the understanding of their effects on perception - and towards the project of architecture and urbanism. This inflection proposes that the students enter the exercise of the know-how of the design practice through the handling of typically architectural elements responding to questions pertinent to the universe of buildings and the city. It is a new pedagogical agenda that aspires to a propaedeutic basis more clearly aligned with recurring issues in the construction of Brazilian cities and that is based on considerations in the fields of theory, history and critic of the architecture.

This article will present aspects of this agenda through the description of the so-called Modulation Exercise - conceived in 2012 by the discipline Conception of Architectural Form II, of the second semester of FAU $U_{F R J}{ }^{1}$ - and of the explanation of the theoretical and architectural premises that underpin the new pedagogical agenda. The exercise largely synthesizes the fundamental aspects of the design approach advocated by the studio. In general, it can be said that the agenda emphasizes a project conception focused on relevant and transcendent aspects of the program, place and construction system, while valuing the adoption of a so-called "elementary" architecture, based on synthetism, elementality of the object and in the adoption of a formal system that relates a restricted number of physical or conceptual elements. This formal system is marked by the use of the resistant structure as the organizer of the project and by the constructive pertinence of the architectural form. Besides being an adjusted tool for teaching and reflection on project practice, this agenda also aligns with the most pressing architectural problems in the construction of Brazilian cities, especially in its peripheral areas, where the architectural project is frequently dismissed. It is important to point out that the agen$\mathrm{da}$ is also linked to the investigations of the research group TEMPU -Theory, Teaching and Methodology of the Urban Project - of which the authors are members. ${ }^{2}$ The group focuses, on the one hand, on the role of the architecture project and its artifacts, repeated or singular, for the construction of the city in the contemporary context of urbanization. In addition, it addresses the impacts of the recent implementation of infrastructure projects in peripheral territories of large Brazilian cities and, recognizing the urgency to think of alternatives for expansion and densification of suburban areas that anticipate the simple spread of informal occupation, proposes new patterns of urbanization based in the so-called "elementary architecture" 
applied in compact housing construction models. In addition to the discipline Conception of Architectural Form II, other FAU UFRJ design studios also reflect the discussions of the research group, incorporating common principles in their teaching approaches. Such alignment provides an environment conducive to the development of common pedagogical agendas, enabling the sharing of concepts, instruments, architectural references and design strategies that could be cultivated by students throughout their education. It is precisely because it is a potential situation, not yet consolidated, that it is necessary to expose, in articles like this one, the premises and strategies that guide teaching in the different studios.

\section{Script: the modulation exercise at FAU / UFRJ}

The Modulation Exercise, applied at the beginning of the semester of the discipline of Conception of Architectural Form II at FAU / UFRJ, is preparatory to the main exercise of the discipline - the design of a small single family house - and consists of the design of a building of up to three pavements, without defined program, in a narrow urban lot characteristic of the Brazilian suburbs, from a modular tridimensional frame (Figures 01 and 02). ${ }^{3}$ The objective is to elaborate an architectural composition based on the manipulation - essentially through physical models and drawings - of an independent structure formed by pillars, beams and slabs.
3 In the discipline universe, the exercise is developed in a short time, approximately 3 weeks.
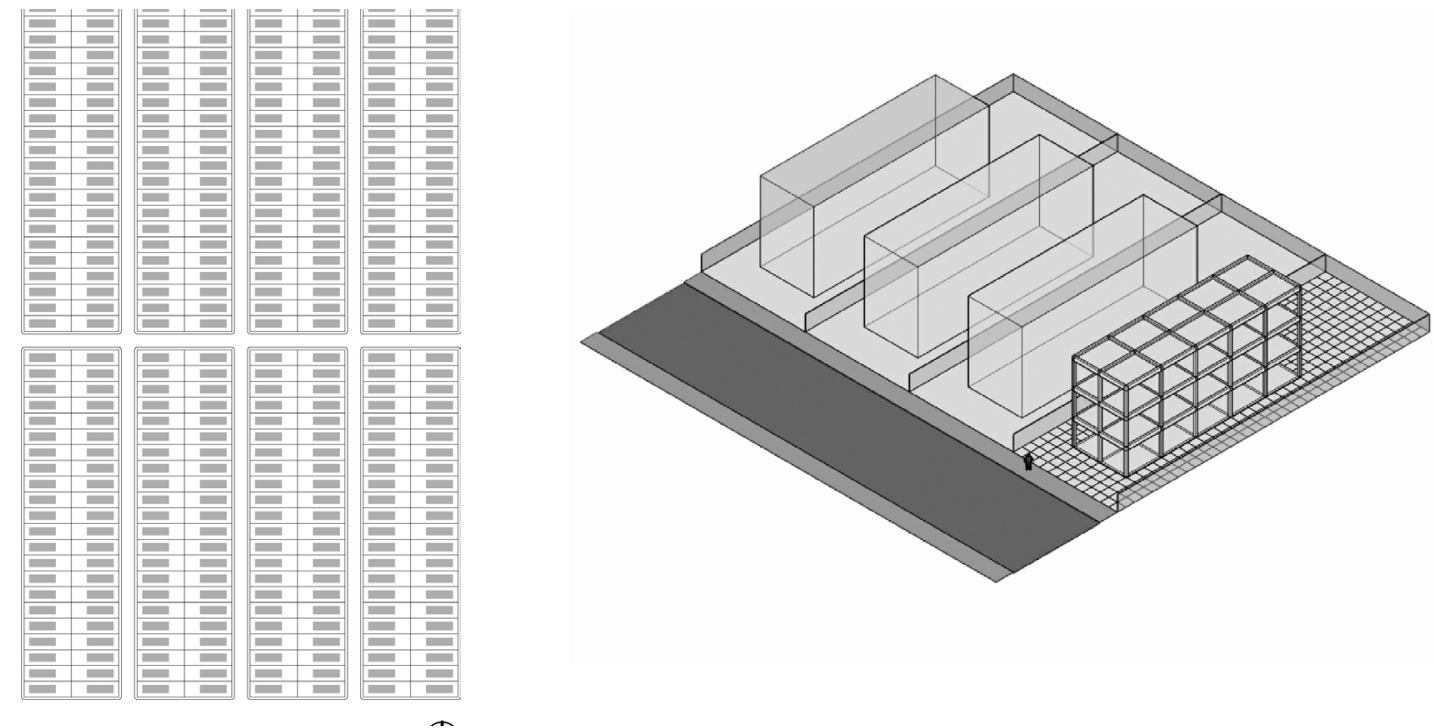
4 Mahfuz, Edson. Edson Mahfuz talks about the systematic processes in the project. Revista AU, May 2009. Available at: http:// au.pini.com.br/arquitetura-urbanismo/182/artigo134779-2.aspx.
The objective is to link the exercise of plastic composition to the use of recurring forms in the universe of civil construction, providing the compositions with an intrinsic constructive pertinence. The modular-visual system that guides the operations of the project is formed by a modular grid of $3 \mathrm{~m} \times 4 \mathrm{~m}$ which is coincident with the resistant structure. The grid, understood as a set of parallel lines that cross orthogonally regular volume, constituted one of the most characteristic systems of modern architecture, although there is no relevant building in which the grid is present as its diagrammatic representation, as it is usually transformed to accommodate the program and to dialogue with the context. ${ }^{4}$ Therefore, a conceptual distinction is made between the formal structure of the project - in which the modular grid lines constitute the computer system - and the resistant structure of the building - where the pillars, beams and slabs appear as physical elements, having the modulation lines as axes. This distinction makes it easy for the student to understand that the presence of a system based on modular ordering offers a set of criteria that guide the arrangement of different parts of a project. (Figures 03 to 04$)$.

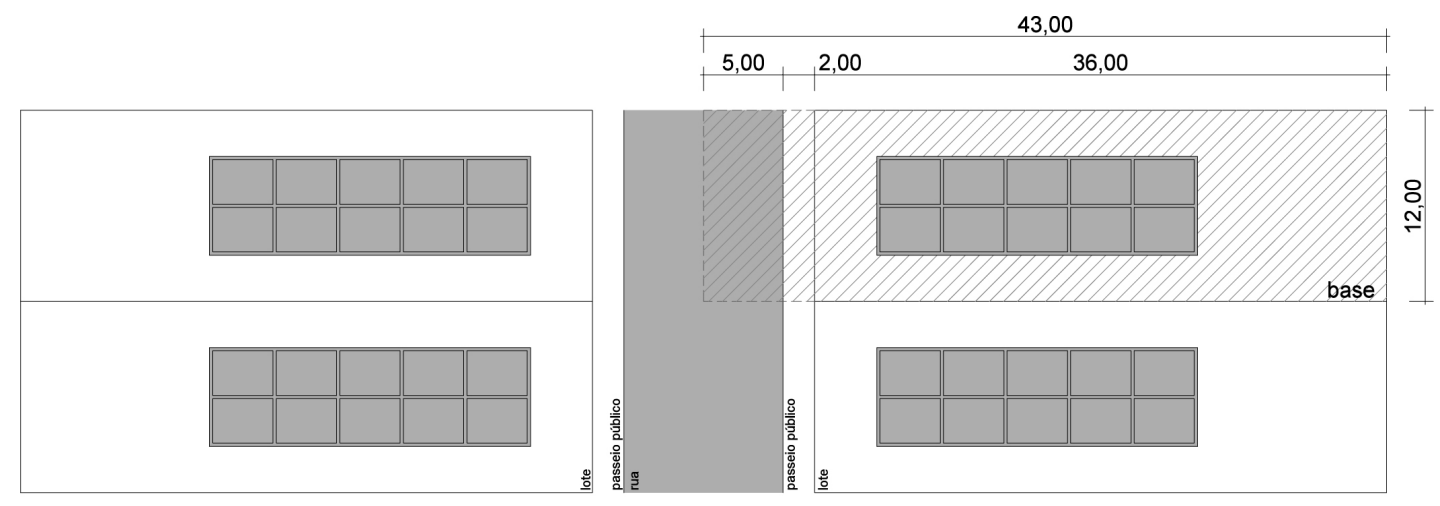

(1)

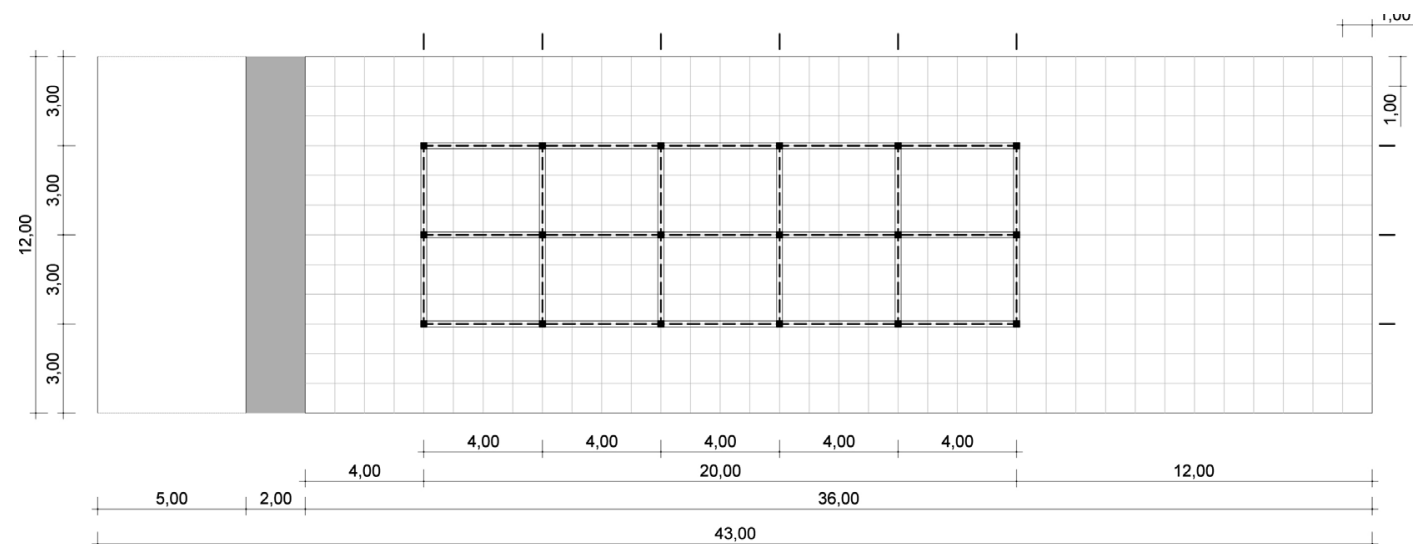

Figures 03 and 04

Site plan showing four lots and the street section formed by their side-by-side joining, and site plan in the lot of the three-dimensional modular frame provided as a basis for the exercise. No scale.

Drawing: Pedro Engel, 2016 
The physical elements of the resistant structure do not have, in the scope of the exercise, material definition. Although reinforced concrete structures are mentioned as the constructive system characteristic of the urban expansion of large Brazilian cities, the exercise treats the beam, pillar and slab elements considering their recurrent formal features as recognizable in city buildings. Basically the beams have rectangular sections and height of $10 \%$ of the span, pillars have square section of $20 \times 20 \mathrm{~cm}$ and slabs are planes with about $10 \mathrm{~cm}$ of thickness. Some rules define pre-sizing to mark the use of balances, any increases in spans or suppression of supports, allowing the student to operate modifications in the structure with clear criteria. (Figures 05 to 06).
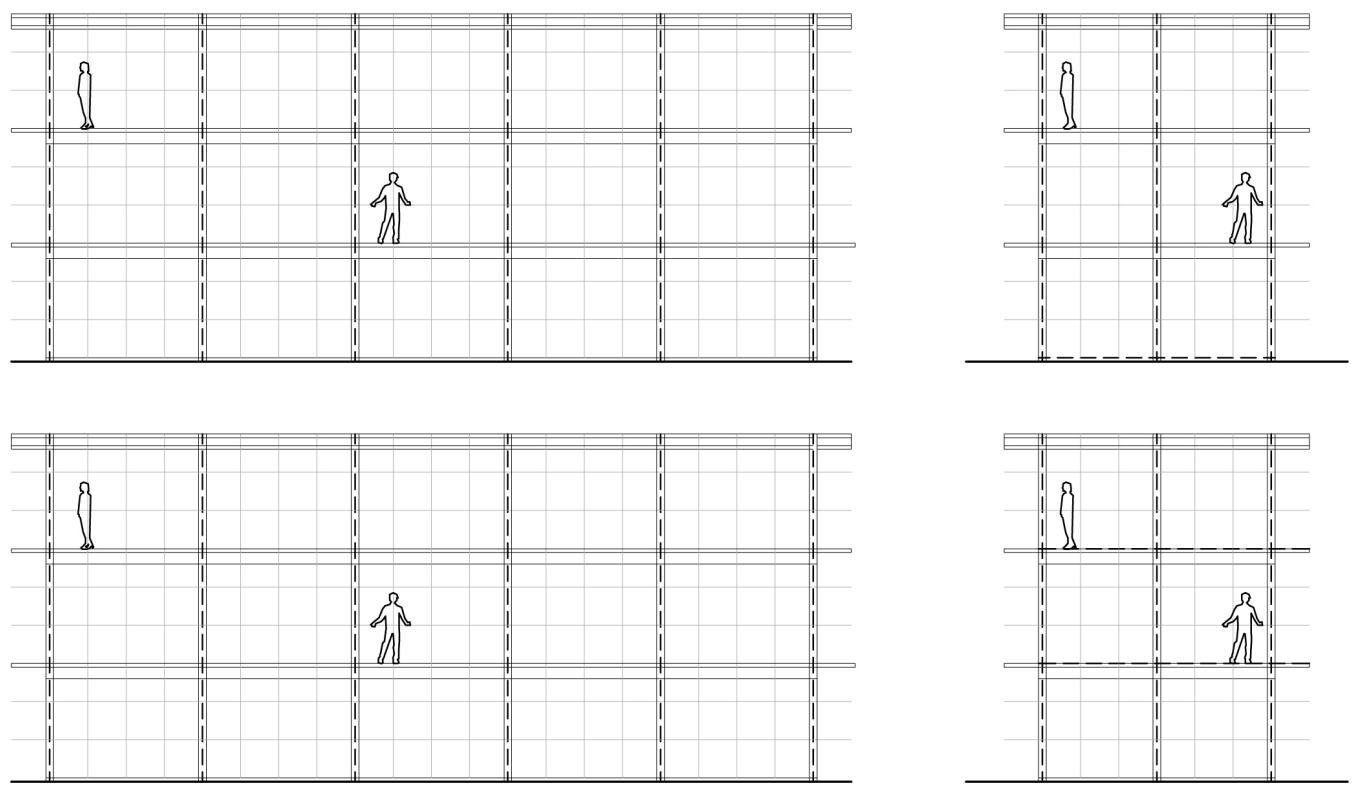

Figures 05 and 06

Longitudinal and transverse sections of the three-dimensional modular frame provided as a basis for the exercise. No scale.

Drawing: Pedro Engel, 2016.

Faced with the common limitations of beginning students - still incipient management of the means of representation; Scarce repertoire of project solutions; Lack of consolidated criteria and difficulty in responding to complex problems - the exercise was conceived as a pre-structured design problem. The complexity of the problem is reduced by "turning off " certain design constraints such as place, program, and materiality, while placing emphasis on the relationships between form, structure, and space. In addition, the possibilities of action are limited and ordered by the adoption of the three-dimensional modular grid and an elementary formal vocabulary, easily manageable, based on 
simple elements and on the use of the right angle. Thus the exercise leaves open, but controlled, a space where compositional research, experimentation and verification of design solutions find fertile ground to be develop.

Since there is no defined program, the statement of the exercise proposes two themes that students should focus on when exercising the manipulation of form: "designing with the void" and "facade as interface". The first one concerns the use of volumetric subtraction as a priority operation of plastic manipulation, which occurs through the creation of spaces such as terraces, pilotis, loggias, intermediate subtractions and internal voids. These design devices are presented in an introductory class through images of examples belonging to the tradition of modern architecture accompanied by a series of graphic schemes that, by means of their diagrammatic character, make it possible to show students not only the strategies of subtraction but also the formal structure adopted in the exercise. In addition, the strategy of designing through subtractions allows us to approach the idea of empty space construction. This seemingly contradictory way of understanding the architectural design - where the void is, so to speak, understood as a positive entity - is made evident both inside the building by means of double ceilings, mezzanines and courtyards, as well as outside, through the articulation of horizontal and vertical planes and of frames that act in the conformation of the empty volume. (Figure 07)
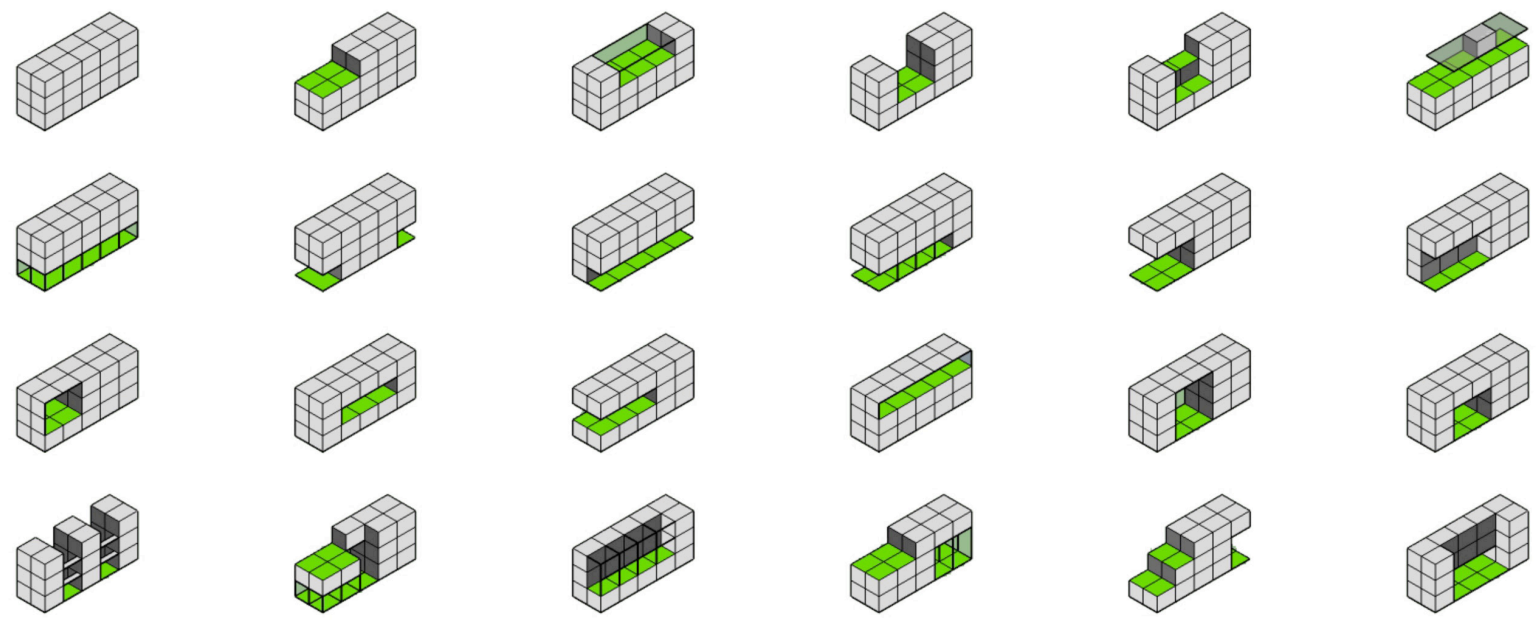

Figure 07

Examples of volumetric manipulation by means of the "designing with the void" shape control strategy. Drawing: Pedro Engel, 2016 
The second theme, facade as interface, is related to the idea of plastic composition of closing envelope of the building. It is based on the understanding that structure and closing elements are not necessarily coincident. This theme is presented in an lecture that discusses the evolution of the independent structure in architecture and the importance of reinforced concrete in the consolidation of the formal system of modern architecture. Beginning students should experience different compositional possibilities relating structure and closure in different ways - on the same plane, on distinct planes, or in hybrid situations. In this way they come into contact with a vocabulary of architectural elements specific to buildings' envelope, such as walls, frames, hollow plans, spans and openings, sun protection elements, verandas, balustrades, balconies, loggias, etc. The facade and its elements appear as ambivalent: on the one hand, it is a space of visual composition that concerns principles such as rhythms and repetition, proportional systems, expression of emphasis, such as horizontality, verticality, centrality, symmetry, asymmetry, etc, ; on the other hand, the envelope is seen as the separation between interior and exterior, thus capable of mediating different aspects of this relationship, such as access, views, privacy, lighting and directs sun incidence. The compositional syntheses conceived by students within the facade as interface should contemplate these aspects in response to the given contextual conditions, as we shall see below.

Combining these two themes as the main "problems" to be faced in the exercise, we seek to give continuity to objectives present in the tradition of bauhaus propaedeutics, especially to the development of intellectual control over form through ordering criteria (in this case modulation) and to the exercise of compositional skills linked to the visual configuration of the form and its aesthetic effects. In this way, the exercise offers the opportunity to counteract a problem found in design teaching today: the arbitrariness that governs the formal and figurative configurations. By relying on logical and recognizable principles, the student acquires greater security in the way of designing, since he becomes apt to know and make use of a universe of formal and figurative relations that obey their own logics from a system that is controlled and identifiable. Thus, the resistant structure ordered by the modular grid is used as an instrument for the recognition of the formal order and for identification of strategies and tactics of design that guide the use of the visual ordering principles; at the same time, when it appears explicit on the façade, the structure can itself be used as a compositional element. 
5 Mahfuz, Edson. Reflexôes sobre a construção da forma pertinente. Arquitextos Vitruvius, 045.02, year 04, February of 2004

6 Thus, it connects with the agenda of the TEMPU group, at the same time as it acts in a search to help reverse the process, still present in Brazil, of the configuration of architecture and urbanism as exclusive or almost opposite fields. The idea of focusing simultaneously on architecture and urbanism considers Le Corbusier's refusal to establish any distinction between these two fields to be correct, since, for him, "urbanism is the support of architecture" (Le Corbusier. Precisões: sobre um estado presente da arquitetura e do urbanismo, São Paulo: Cosac \& Naify, 2004, page 78). Le Corbusier, however, was neither the first nor the only to look at this problem. Still in the nineteenth century, Camillo Sitte addresses the same issue. Sitte treats the city as a work of architecture, and investigates, from this, the urban possibilities of architecture, such as proportions, and ways to insert and combine not only buildings but also monuments in public spaces. Sitte also explores the aesthetic potential of some urban elements, such as land use, building alignment, circulation flows, density and vegetation (Sitte, Camillo, Vienna: Verlag Carl Graeser, 1889. In: Http://www.architekturtheorie. tu-berlin.de/architekturtheorie/menue/architekturtheorie/). Already in the 1950s, we highlight the effort undertaken by Josep Sert during CIAM 8, under the theme "The Heart of the City". Sert argues that since CIAM 2, Frankfurt, 1929, there was already a recognition that no clear line of separation could be drawn between the study of the architectural problems of urbanism, and the congresses would then address both fields in all encounters (Tyrwhitt, J, Sert, JL, Rogers, ENCAM 8 - The Heart of the City: Toward the Humanization of Urban Life London: Lund Humphries, 1952).
In addition, the universe of forms to which the exercise is attached refers directly to recognized architectural elements - pillars, beams, slabs, walls, stairs, balconies, frames, sun protection elements, floors, ceilings, roofing. These constitute the parts and foundations that compose buildings. Thus, the exercise presents itself as an opportunity for students not only to expand their knowledge and repertoire of such elements of architecture, but also to exercise possibilities of combinations and ways of articulating them. In addition, the conditions proposed by the exercise become facilitators of compositional processes, allowing students, even beginners, to tackle relatively complex and typically architectural issues such as relationships between three-dimensional forms.

The use of the module and the three-dimensional modular grid, in turn, brings a number of advantages - perhaps obvious or more easily perceived by more experienced students or architects, but whose explicitness, practice and fixation is pressing for beginning students - related to efficiency both in terms of design and construction. Modulation as a compositional procedure makes it possible, on the one hand, to operate systematically, which, according to Mahfuz, assists in the "definition of compositional rules that guide both the definition of larger parts and smaller parts of a project." ${ }^{5}$ On the other hand, it simplifies the preparation of the project and construction, since it facilitates and makes the combination of measures more flexible. In this way, a significant reduction in the variety of types and dimensions of its components, standardization of detail and dimensional accuracy, reduction in material breakage, increased productivity in the execution of the building (and the model), and finally, optimization of techniques and processes. (Figures 08 to 17)

Finally, some words should be said about the contextual definition of the exercise. By suggesting the creation of a stretch of street by means of positioning side-byside the lots of each student, minimum information is generated regarding to the urban situation of the projects. Although it is not a specific place in the city, the conditions generated allow us to present typical elements of the parceling of lots characteristic of the urban expansions in the suburbs of Rio de Janeiro and other Brazilian cities - street, public walk, block, lot. In this way the exercise operates as an instrument to think architecture together with the urban space, as well as to discuss the role of the architecture design in the constitution of the city. 6 Moreover, such conditions generate contextual forces to which students must respond when operating with volumetric subtractions 

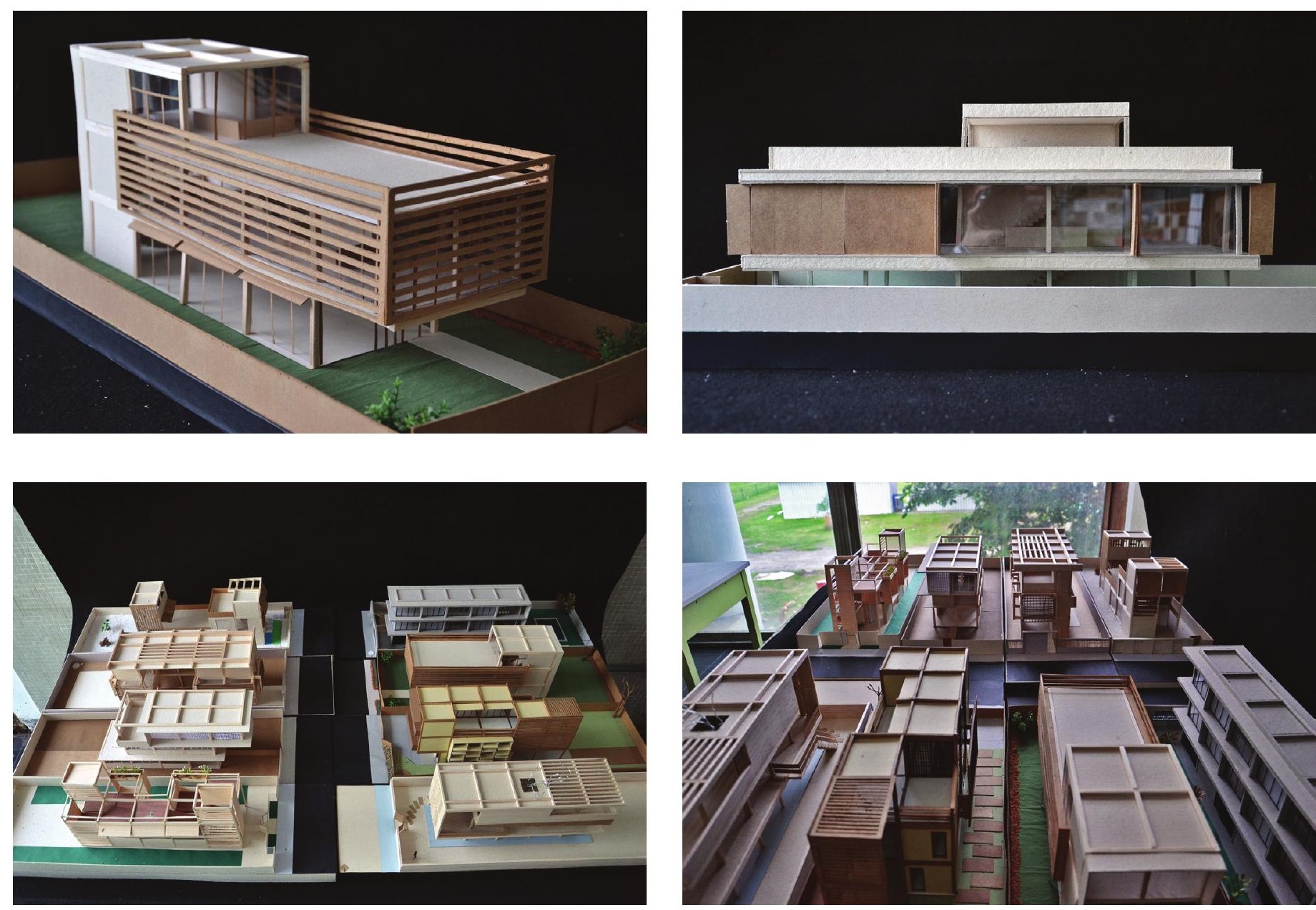

Figuras 08 a 17

Trabalhos de alunos realizados em 2016-01.

Fotos: Mara Eskinazi, 2016.

\section{Historical references: the nine-square problem, or structure $x$ space}

The nine-square problem is used as a pedagogical tool in introducing architecture to new students. Working with the problem, the student begins to discover and understand the elements of architecture. Grid, structure, group, panel, center, periphery, field, boundary, line, plane, volume, span, comprehension, tension, cut, etc. The student begins to explore the meaning of plane, elevation, cut, and detail. He learns to draw. He begins to understand the relationships between two-dimensional drawings, axonometric projections, and the three-dimensional (model) form. The student studies and draws his scheme in plan and axonometric, and looks for the three-dimensional implications in the model. An understanding of the elements is revealed, a fabrication idea emerges. (HEJDUK, 1985, p: 37)

The proximity of John Hejduk's description of the ninesquared problem with the exercise in question here makes explicit its origin. The modulation exercise currently applied in the second semester at FAU / UFRJ was based on the most enduring and widespread initial 
post-war design problem in architectural teaching. The exercise was instituted in Hejduk's classes officially in 1954 at the University of Texas at Austin, but was disseminated throughout the network of American architecture schools after World War II and developed into a didactic strategy generally known as kit of parts.

In it, Hejduk presents a structure with a square base floor formed by a grid of pillars, beams and slab, and asks students to build their model on the $1 / 25$ scale and draw their 30/60 isometric perspective; from there, he uses three-dimensional models and drawings as basic working tools for research and study. Hejduk suggests that the exercise of the nine squares allows the student to pass between two poles, that of complete fluidity and contention; Besides, it allows to elaborate the ideas of center and periphery, since its diagrammatic scheme presents / displays one central and eight peripheral cells. It proposes a sequence of steps to be worked on for addition and articulation of the elements, which include insertion of linear and curved panels, diagonal panels, volumes, series with different combinations between columns and panels, through the insertion of architectural elements such as stairs, ramps and even the inclusion of more pavements. With this, the three-dimensional modular frame, which is explicit through the models, provides the inputs and the context for the architectural operations, based on the addition of elements. And the drawings are used for the elaboration of pedagogical and projective diagrams of Bauhausian inspiration that act by highlighting the potentialities of the form and indicating the forces of its own emergence and, as a result, operate as a tool for the sequential approach of design decisions. Thus, the problem of nine-squares is posed as a pedagogical device for the configuration of a basic method of architectural construction based on the binomial space and structure as favoring the articulation of plastic-formal relations. (Figure 18)
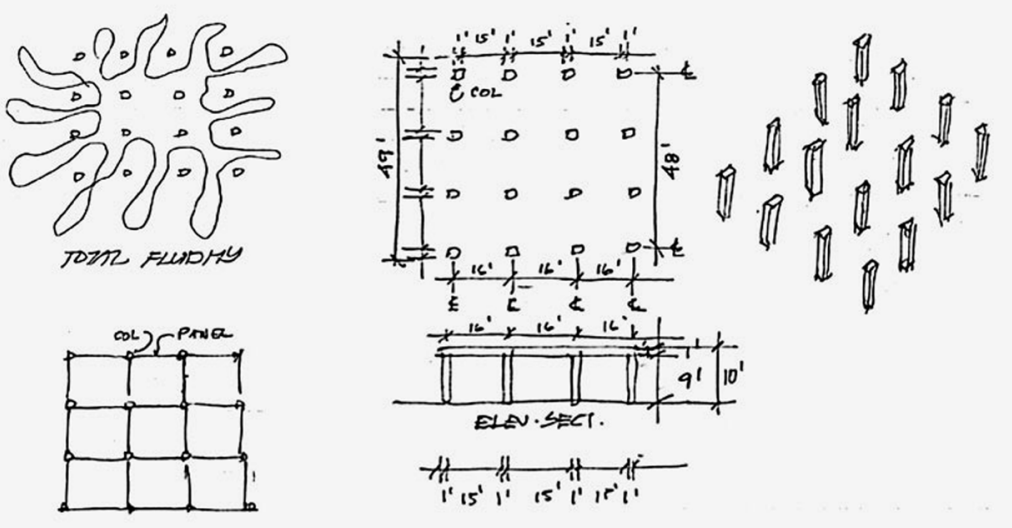
7 Comas, Carlos Eduardo Dias. Arquitetura moderna, estilo Corbu, $\mathrm{Pa}$ vilhão brasileiro. In: Revista $\mathrm{AU}$, number 26 , p. 94
Such a method emerges essentially from the fusion of two modern diagrams - Le Corbusier's Domino System (1914-1917), as representative of the structural questions, and the axonometric Contra-Construction of Theo van Doesburg and Cornelis van Eesteren (1923), referring issues related to space.

Dom-inó (from the Latin dooms, "house", and an abbreviation for "innovation") is a constructive system consisting of precast elements - flat slabs, pillars and foundations in reinforced concrete - combinable in various ways, open to be subdivided in different ways and, consequently, to any spatial interpretation. This system, based on the idea of an independent structure or skeleton, is the technical-constructive foundation of modern architecture, and Corbusier's design emphasizes both the combinatorial character of the architectural game and the "authority of the rule without which no game can begin".7 The Domino System also fulfills the role of representing the rupture in the technique revealed by the passage of the stone construction, where structure and walls are necessarily coincident, to a reinforced concrete construction with independent structure, where the structural and closing systems become independent elements and no longer necessarily coincident. Such independence is also a central issue in the Modulation Exercise, since the consideration of the resistant structure and the closure plane as independent and not necessarily coincident systems has a direct influence on the strategies of form control related to the theme of the facade as an interface as well as the alternatives of internal space explorations. (Figure 19)

The Contra-Construction, axonometric perspective of Theo van Doesburg and Cornelis van Eesteren was conceived as a reflection on a new spatial and structural model. In it, horizontal and vertical planes define a set of asymmetric volumes around an open central core. However, the plans have an atheistic character, divorced from the function of bearing. The elevation of the view point allows you to see multiple sides at the same time, but does not give clear understanding of what is front, side, back, inside or outside. However, typically architectural elements, such as walls, frames, floors, slabs, roofing, etc., are eliminated. That is, the Contra-Construction explains the essence of the way of thinking of the constructive vanguard, especially neoplasticism, whose ideas of form culminated in the theoretical basis and on the formal and spatial language characteristics of modern architecture, and is key to understanding its objectives. Thus, it becomes a pertinent model for abstract explorations of spatial relations. (Figure 20 ) 


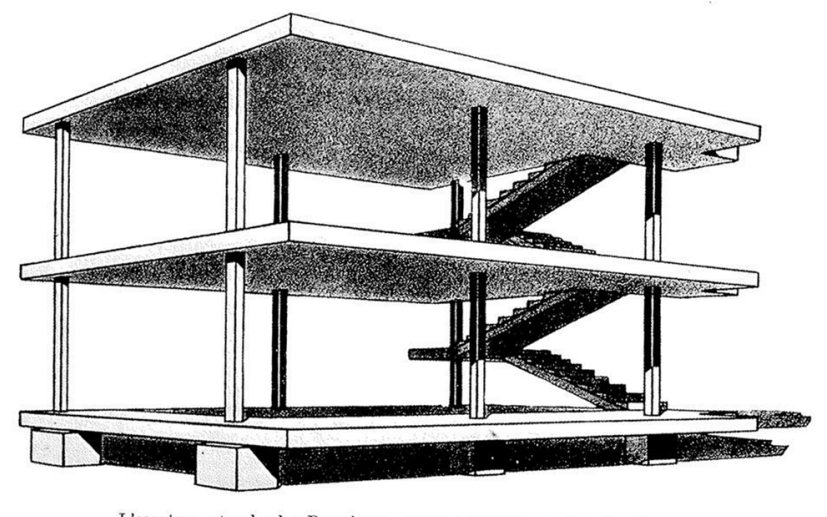

L'ossature standard «Dom-ino", pour exécution en grande série

Figures 19 and 20

Dom-inó Structure and Contra-Construction.

Source: Corbusier, 1964, p: 23 and www.moma.org

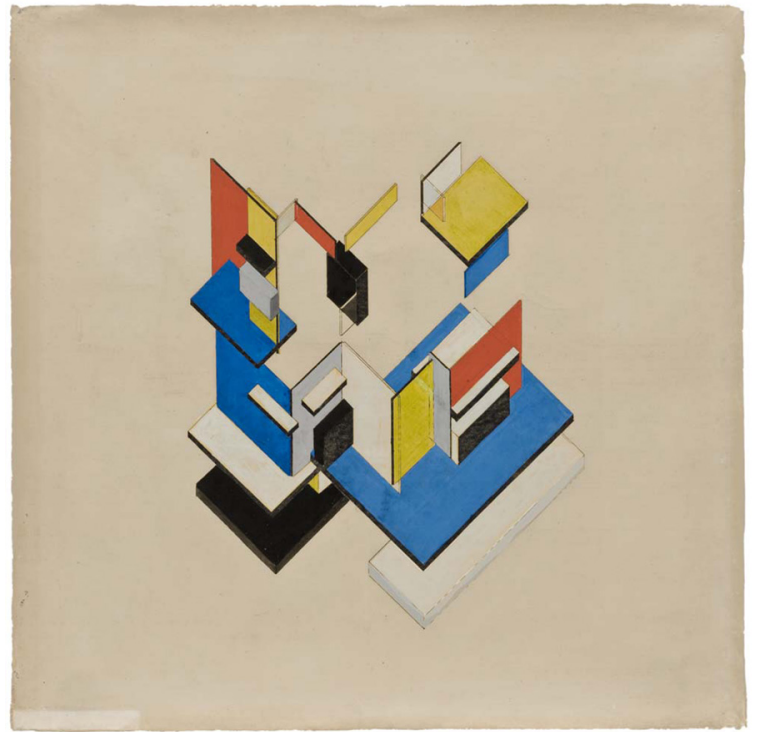

Domino and Contra-Construction, coupled with Rudolph Wittkower's planimetric logic that permeates his analysis of the 11 villages of Palladio and the synthesis diagram of what would be the "twelfth village" (Figure 21) provided for the nine-square problem, and consequently, for the exercise here in question, the disciplinary basis of modern architecture, founded on the plastic and spatial inventions of cubism and on the articulation of logics as center and periphery, vertical and horizontal, inside and outside, frontality and rotation, solid and empty, etc.

However, to the idea of linking the nine-square problem directly with the modern vocabulary, one can add the view of Love, which argues that, by focusing on the purity of autonomous architectural problems, the exercise also is drawn towards American minimalism. For him, the conceptual boundaries and design strategies employed in part kit exercises are more formally close to those that characterize the work of artists such as Sol Le Wit and Donald Judd than to the traditional two-dimensional compositions in history and art theory. ${ }^{8}$

Following the exercise of the nine squares, as a result of his search for principles that generate form and space in architecture, and with the objective of experiencing the limits and potentialities of the theoretical and pedagogical bases that underlie the exercise, Hejduk develops between 1954 and 1963 a series of seven houses called "Texas Houses". (Figure 22) Dedicated to Rowe and Slutzky, the Texas Houses were developed as variations of the idealized diagrams in the exercise, and rely on the primacy of the diagram as a
8 Love, Timothy. Kit-of-Parts Congazine, número 19, 2003. ceptualism. In: Harvard Design Ma- 

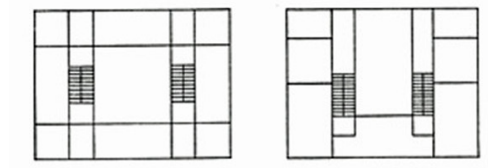

Villa Sarego at Miega
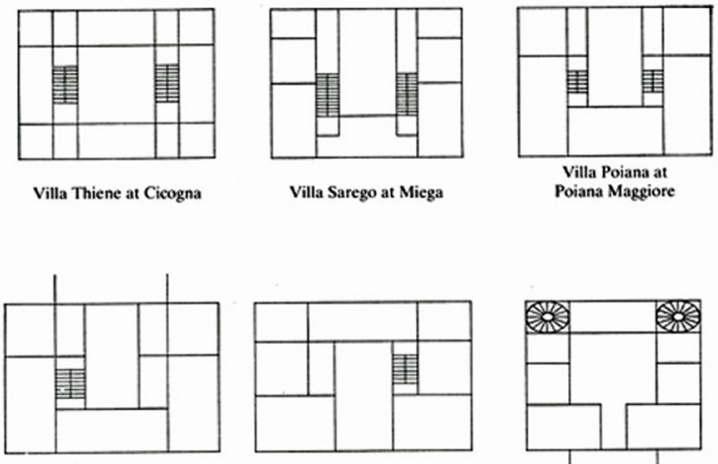

Villa Badoer at Fratta.
Polesine
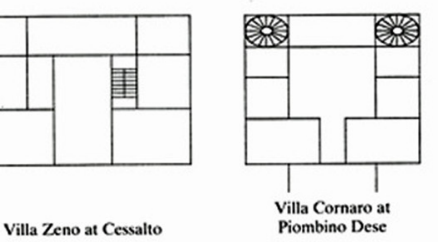

Villa Cornaro at
Piombino Dese

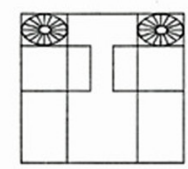

Villa Pisani at Monatagnana

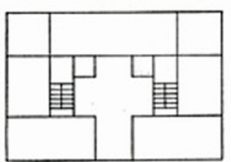

Villa Pisani at
Bagnolo
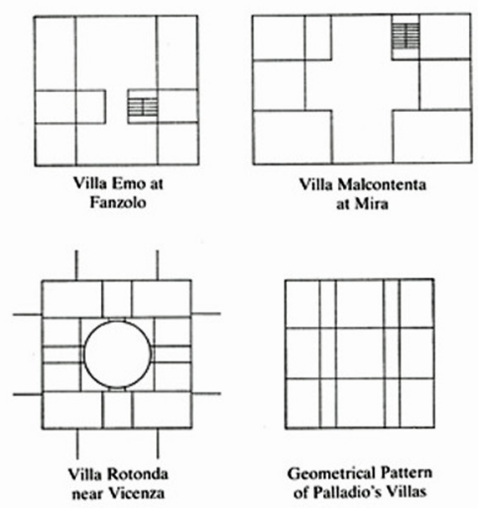

means to explore architectural principles that persist in history, generating complete architectural designs. With this, they can be thought in analogy to Wittkower's diagrams for the Palladian villas.

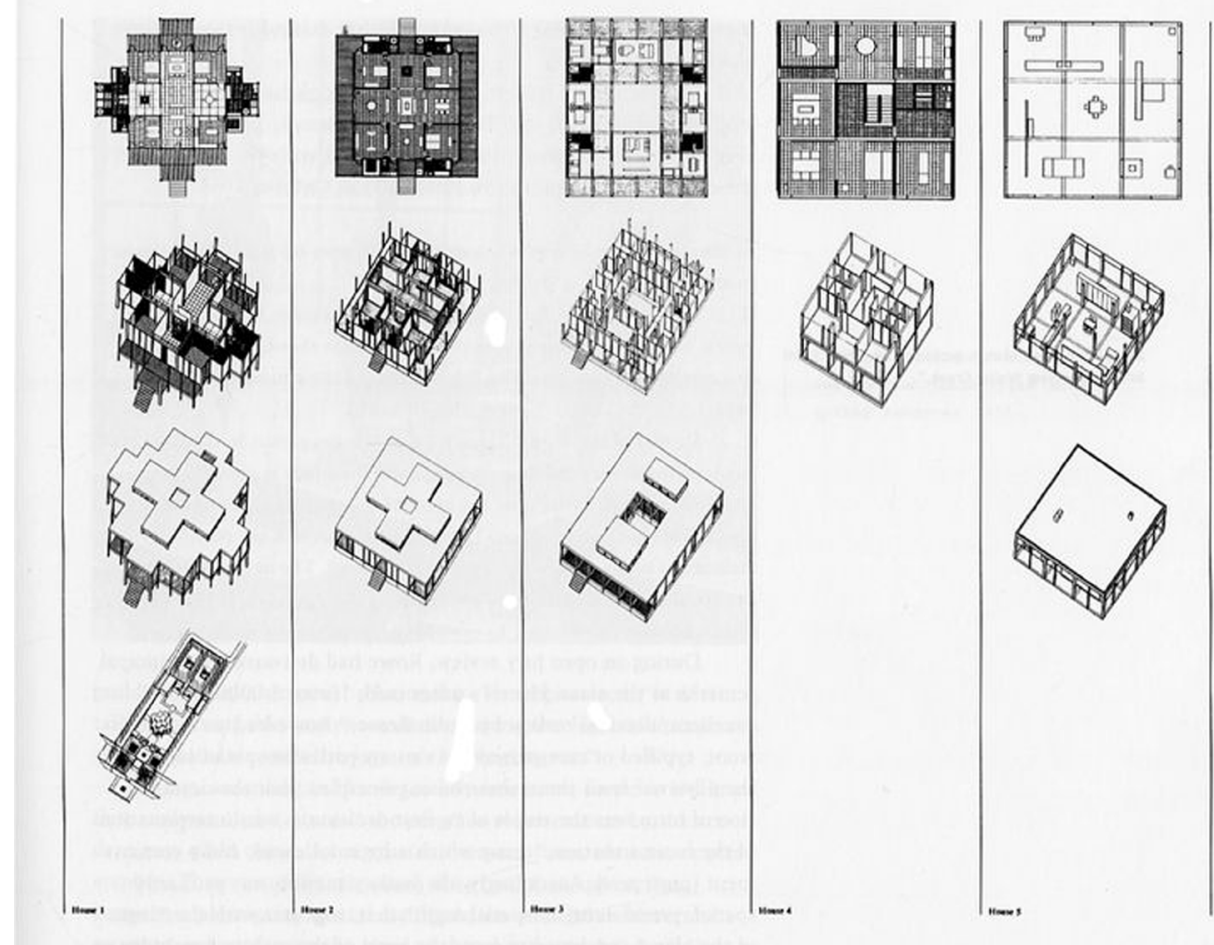

Figures 21 and 22

Wittkower diagrams for the Palladian villas, and Hejduk Texas Houses. Sources: www.smallhouselab.com and Hejduk, 1985, p: 223-233.

That is, both the exercise of the nine squares and the projects that departed from it, as well as its derivation currently applied in FAU / UFRJ, have in common the pertinence of putting itself as a tool that allows, at the same time, to face a body of introductory teachings in an abstract way, operating in the context of a problem of conception, allied to typically architectural issues and the introduction of a set of architectural elements. The artifices that allow the achievement of these objectives are linked, on the one hand, with the pre-structuring of the exercise, and, on the other hand, with its linkage to the architectural vocabulary of modern architecture - which reveals a position regarding the history of architecture. The reduction of the possibilities of action and the supply of material resources are strategies compatible with the skills of the students, still scarce and in the process of formation. Already the repertoire of solutions of elements of architecture and of strategies of composition offered by the modern architecture is used as way to teach and to conceive architecture. In other words, the exercises allow students to engage in design activi- 
ties, albeit with limited resources for spatially thinking and graphing, while being prepared to cope with more complex problems.$^{9}$

\section{Form x structure $x$ space}

In the Modulation Exercise, to the dialectic between space and structure inherited from the exercise of the nine squares, we add the item form, trying to understand the term as the structure of relations that govern a project, or as the synthesis between program, place and construction techniques, obtained by means of a visual order. ${ }^{10}$ By reducing the possibilities of design solutions through the use of a well-known repertoire of architectural elements already widely tested in buildings linked to the modern tradition and in its contemporary manifestations, the exercise forces the student to focus on the spatial relationships potentialized by the trinomial form $x$ structure $x$ space, which leads to the identification of an idea of form related to the modern concept of structure. For Mahfuz, in modern architecture, form refers to the relational structure or system of internal and external relations that configure an artifact or architectural episode and determine its identity. ${ }^{11}$ That is, the delimitation of a conceptual basis is one of the keys to the structuring of the exercise and to the exploration of architectural issues related to formal manipulation. In addition, the articulation and combination of the elements of architecture through the principles of synthetism and visual elementarity are also used as tools for the configuration of the shape of the object.

\section{The tridimensional frame}

In Chicago Frame, Rowe states that the frame, or three-dimensional plot, is the essence of modern architecture. For him, although the three-dimensional plot had appeared explicitly and without disguise in different parts of the world, its role, the explication of its universality, as well as the elucidation of its formal results, were anticipated with the commercial architecture produced In Chicago in the last decades of the 19 th and early 20th centuries. Analogously to the crucial link that can be established between Renaissance architects and Florence, or between Gothic architects and Ile-de-France, modern architects can be linked to Chicago through the role played by the three-dimensional frame in the establishment of spatial-spatial relations in this context. ${ }^{12}$ In addition, it is worth mentioning the also umbilical relationship between the impetus of urbanization present in the context of Chicago and the role of the three-dimensional frame
9 Engel, Pedro. Cubos, tramas e jogos de armar. Notas sobre exercícios de concepção da forma no ensino de introdução ao projeto de arquitetura. Rio de Janeiro, 2011, pp. 13-14.

10 Mahfuz, 2004, op. cit.

11 Mahfuz, 2004, op. cit.

12 Rowe, Colin. Chicago Frame. Em: The mathematics of the ideal villa and other essays. Cambridge: The MIT Press, 1976, pp. 90. 
13 Rowe, 1976, op. cit., p. 90. as an effective and economically viable architectural response for the development of such urbanization. ${ }^{13}$

The three-dimensional frame establishes with the building a logic or common system according to which all parts are related or subordinate. If the independent structure delimits a neutral spatial grid that provides some symbols, and for this reason establishes relations, defines the discipline, and, with this, acts in the generation of the form, the three-dimensional frame, in turn, besides defining a position for the resistant structure is also used as an instrument that guides the compositional configuration of the whole, thus acting as a spatial reference device. Thus, the three-dimensional frame has acted as a catalytic element of architecture - in some cases becoming even the architecture itself - to an extent that, for Rowe, the then contemporary architecture would be inconceivable in its absence.

In the Modulation Exercise, the three-dimensional plot is directly linked to the use of the module as a regulatory measure and organizational structure of the project, since the plot and modulation are coincident and parts of the same system. In addition, the three-dimensional frame provides at the same time the context for subsequent architectural operations, and the system within which architectural elements will be added. Thus, from the consideration of its universality, allied to the strategies of designing with the void with the use of volumetric subtraction as an operation of plastic manipulation, the three-dimensional frame plays a fundamental role as a producer of spaces. This is because it operates, from the pedagogical point of view, as a device that provides an instrumental basis where the student can rely on the most diverse stages of the design process - at the initial moment of conception, in the hierarchy of solutions, as well as in their verification. That is, although its essential elements are limited by pedagogical intentions, the potential of the three-dimensional frame as a space and form generating system is conceived as an open manipulation device.

\section{Final considerations: the architectu- ral project and the construction of the city}

\section{Models of housing expansion and the role of the structure}

The agenda of the TEMPU research group focuses on the role that the architecture project can play as a cat- 
alyst in the city's constitution and its relationship with the contemporary context of urbanization. It is about exploring the role of architecture as city construction and the reclaiming the urban sense of civitas. ${ }^{14}$ From this, one tries to understand the city as a sum of the concrete artifacts, whether repeated or singular, that constitute its urban spaces.

Este tema se relaciona, na realidade das cidades brasileiras, por um lado, com os impactos causados pela implementação de novos projetos de infraestrutura em áreas pouco urbanizadas dos subúrbios; por outro, com o ressurgimento, nos anos recentes, da "cidade informal" no discurso e na prática da arquitetura e do urbanismo. Tais fatores, aliados, tem determinado um alastramento de expansões habitacionais com ocupação de caráter informal nas áreas periféricas das cidades brasileiras. Em função disso, se torna imperativa a discussão e a experimentação de alternativas para a expansão dessas áreas que antecipem-se a simples propagação da ocupação de cunho informal, propondo novos padrões de urbanização para as cidades brasileiras.

This issue is related, in the reality of Brazilian cities, on the one hand, with the impacts caused by the implementation of new infrastructure projects in underdeveloped areas of the suburbs; on the other, with the resurgence in recent years of the "informal city" in the discourse and practice of architecture and urbanism. Allied factors have led to an expansion of housing expansions with informal occupation in the peripheral areas of Brazilian cities. Due to this, it becomes imperative to discuss and experiment with alternatives for the expansion of these areas that anticipate the simple propagation of informal occupation, proposing new patterns of urbanization.

The Modulation Exercise is seen here as a feeder for research, as an instrument for experimenting with formal and architectural alternatives inscribed within a given construction system. This is more explicit and connected to the discipline's agenda, exploring the role played by a simple structural system - composed of beams, pillars and slabs in reinforced concrete, allied to a three-dimensional modular plot, which has been extensively reproduced in the suburbs Brazilians - as a pertinent tool for the use of the so-called "elementary architecture" in the construction of cities. In this sense, there are some considerations about the role played by the structural system adopted in the exercise as a pedagogical and project research tool.

Le Corbusier, in developing his model for the Domino system, used two main sources as inspiration: the
14 In Toward the Archipelago, Aureli Defines the concept of civitas differentiating it from that of urbs. For him, while urbs designates a generic and universal condition of cohabitation, or a simple and generic aggregation of persons and houses, civitas refers to an agglomeration of free individuals who come together to recognize and divide a common public sphere, and is precisely the Sharing this domain which provides them the status of citizens. In: Aureli, Pier Vittorio. Toward the Archipelago. Nova York: Anyone Corporation. Log, number 11, winter if 2008, pp. 91-120. 
15 Aureli, Pier Vittorio; Giudici, Maria S.; Issaias, Platon. From Dominó to Polykatoikia. Domus, number 962, October of 2012. Available in: http://www.domusweb.it/en/architecture/2012/10/31/from-dom-inoto-em-polykatoikia-em-.html wooden pillared buildings in Turkey, and the houses in the Flanders region. Both references refer to the idea of looking closely at the systems of vernacular construction and the constructive processes that constitute the daily life of cities. However, in Dom-inó, Le Corbusier combines the logic of a typically industrial system with the new possibilities arising from concrete construction. In addition, it should be remembered that Le Corbusier's system was developed, in his own words, "for execution in a large series". That is, in the context of reconstruction after World War I, the urgency of housing reconstruction would require the development of new flexible methods for housing construction. 15

In this sense, the discipline's agenda proposes the adoption of a structural system of pillars, beams and slabs in reinforced concrete, found in supposedly spontaneous and informal construction sites, such as favelas or suburbs of Brazilian cities, as a tool for the production of structures for the ordinary. This constructive system, based on Dom-inó, is generic, adaptable and flexible, which makes the selection of the forms and rules of combination between them appropriate for the experimentation of both spatial articulations through the use of volumetric subtraction, as well as configurations through the strategies of composition of the façade as an interface. That is, the exercise has the geometric format ideal for understanding the interrelationships between the components of the building in terms of their spatial and formal qualities. Moreover, it is compatible with the means of industrial production and with the constructive means available in the Brazilian reality, which makes it, at the same time, very close to the reality of many students currently attending FAU / UFRJ - as well as the needs and demands for housing construction in Brazilian cities.

The exercise also enables, at the same time, by joining the lots side by side, the perspectives related to the proposition of a morphological model of housing construction based on the idea of compact city construction, in low height and high density. Such a model could be developed, at a later stage, also by transforming the connective tissue of housing into collective urban forms from its connection with urban elements such as the block, the courtyard, the street and the ground floor - in essence, the most collective layer of the city. 


\section{For an elementary architecture for housing construction in the suburbs of Brazilian cities}

The design teaching agenda for the discipline of Design of Architectural Form II, which synthesizes and closes the cycle of the first year of the architecture course at FAU / UFRJ, is aligned with the agenda of the TEMPU group insofar as the mode of teaching seeks to be compatible with a way of thinking the construction of the city. Beyond the preoccupation with internal and essential issues to the discipline that articulate themes such as composition, space and movement, natural light control, relationship between elements, relationship between interior and exterior, appropriateness of space to use, structure control, response to context, the design teaching agenda for beginner students relies on a reflection on design principles based on the synthetism, visual elementality of the project and the use of basic forms combined in a formal system compatible with the available constructive means. These principles, coupled with spatial concepts and urban guidelines, may be able to guide the residential occupation of the suburban territories of Brazilian cities, thus anticipating the more informal occupation. This is because they are adequate to the Brazilian reality with respect to an architectural language based on the production of architectural structures for the ordinary or in the use of the so-called elementary architecture in the study of models and patterns for the housing construction of the outlying areas of Brazilian cities.

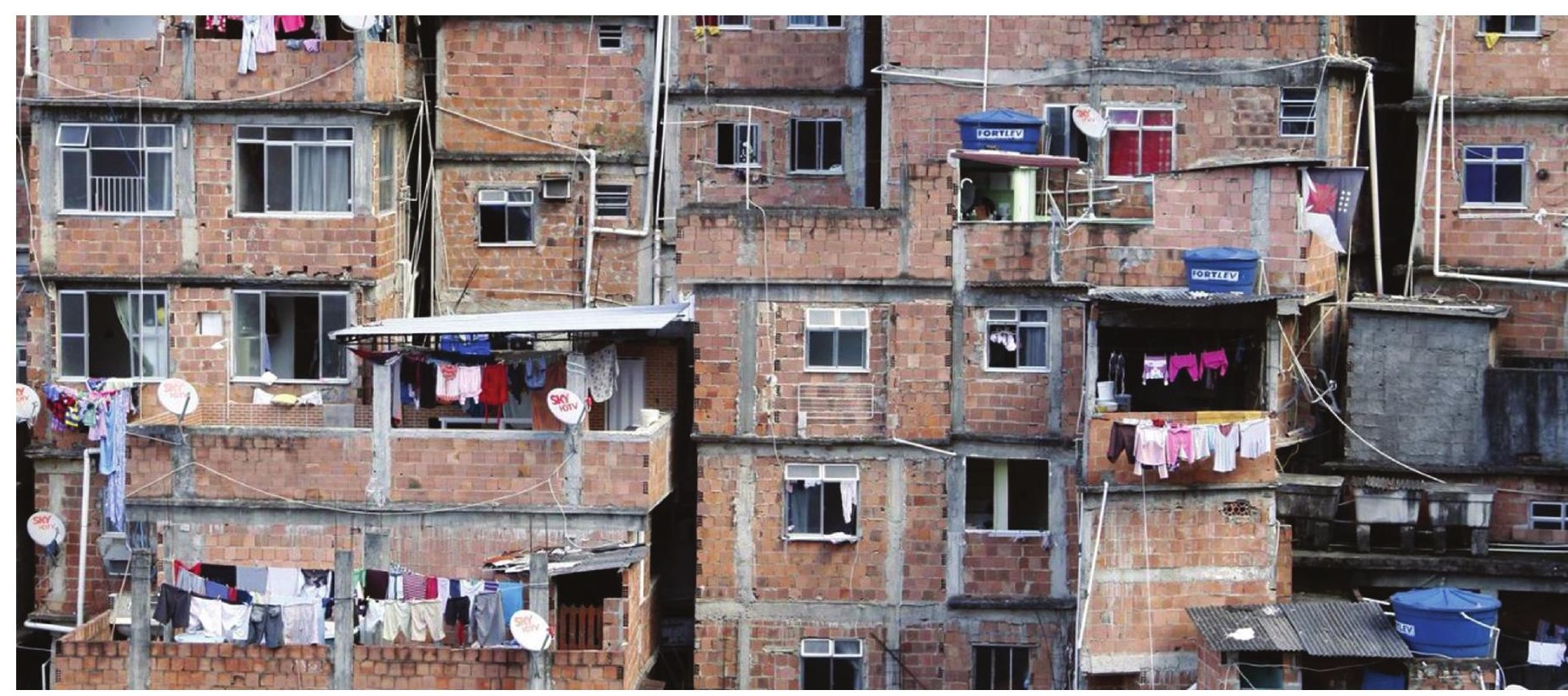

Figure 23

Typical informal occupation in Brazilian favelas. The buildings are based on a simple constructive system of pillars, beams and concrete slabs.

Source: www.oglobo.globo.com 


\section{References}

ALMEIDA, Paulo R. Sobre o ensino do projeto. Dissertação de Mestrado. Porto Alegre: PROPAR/ UFRGS, 2001.

ARIS, Carlos Marti. Silencios Elocuentes. Barcelona: Edicions UPC, 1999.

AURELI, Pier Vittorio. Toward the Archipelago. Nova York: Anyone Corporation. Revista Log, número 11, inverno de 2008, pp. 91-120.

AURELI, Pier Vittorio; Giudici, Maria S.; Issaias, Platon. From Dom-inó to Polykatoikia. Revista Domus, número 962, outubro de 2012.

BALMER, Jeffrey e SWISHER, Michael T. Diagramming the Big Idea. Methods for Architectural Composition. Nova York: Routledge, 2012.

COMAS, Carlos Eduardo Dias (Org.). Projeto Arquitetônico: Disciplina em crise, disciplina em renovação. São Paulo: Projeto CNPq, 1985.

EISENMAN, Peter. The formal basis of modern architecture. Baden: Lars Müller Publishers, 2006.

ENGEL, Pedro. Cubos, tramas e jogos de armar. Notas sobre exercícios de concepção da forma no ensino de introdução ao projeto de arquitetura. Rio de Janeiro, 2011.

HEJDUK, John. Mask of Medusa. Works 1947-1983. Nova York: Rizzoli, 1985.

LE CORBUSIER; JEANNERET, Pierre. Ouevre Complete - Volume 1, 1910-1929. Zurique: Les Editions d'Architecture Artemis, 1964.

LE CORBUSIER. Por uma arquitetura. São Paulo: Perspectiva, Ed. da Universidade de São Paulo, 1973.

LOVE, Timothy. Kit-of-Parts Conceptualism. Em: Harvard Design Magazine, número 19, 2003.

MAHFUZ, Edson. Reflexões sobre a construção da forma pertinente. Arquitextos Vitruvius, 045.02, ano 04, fevereiro de 2004.

PIÑON, Helio, Teoria do Projeto. Porto Alegre: Livraria do Arquiteto, 2006.

ROWE, Colin. Chicago Frame. Em: The mathematics of the ideal villa and other essays. Cambridge: The MIT Press, 1976, pp. 89-117.

ROWE, Colin e SLUTZKY, Robert. Transparency: literal and phenomenal. Em: The mathematics of the ideal villa and other essays. Cambridge: The MIT Press, 1976, pp. 159-183.

SOMOL, Robert E. Texto sonso, ou a base diagramática da arquitetura contemporânea. Em: Risco, Revista de Pesquisa em Arquitetura e Urbanismo. São Paulo: Programa de Pós-Graduação do Departamento de Arquitetura e Urbanismo, EESC-USP, 2007, pp.179191.

WITTKOWER, Rudolph. Palladio's fugal system of proportion. Em: Architectural Principles in the age of humanism. Nova York: W. W. Norton and Company, 1962. 